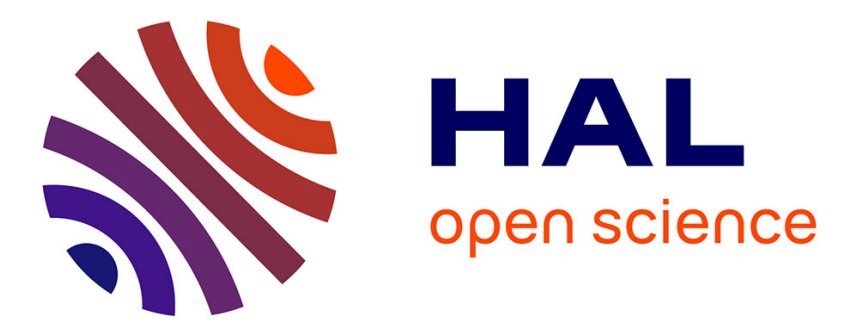

\title{
Making visible the invisible. A microarchaeology approach and an Archaeology of Color perspective for rock art paintings from the southern cone of South America
}

Marcela Sepúlveda

\section{To cite this version:}

Marcela Sepúlveda. Making visible the invisible. A microarchaeology approach and an Archaeology of Color perspective for rock art paintings from the southern cone of South America. Quaternary International, 2021, 572, pp.5-23. 10.1016/j.quaint.2020.05.031 . hal-03264220

\section{HAL Id: hal-03264220 \\ https://hal.sorbonne-universite.fr/hal-03264220}

Submitted on 18 Jun 2021

HAL is a multi-disciplinary open access archive for the deposit and dissemination of scientific research documents, whether they are published or not. The documents may come from teaching and research institutions in France or abroad, or from public or private research centers.
L'archive ouverte pluridisciplinaire HAL, est destinée au dépôt et à la diffusion de documents scientifiques de niveau recherche, publiés ou non, émanant des établissements d'enseignement et de recherche français ou étrangers, des laboratoires publics ou privés. 


\title{
Making visible the invisible. A microarchaeology approach and an Archaeology of Color perspective for rock art paintings from the southern cone of South America.
}

Marcela Sepúlveda ${ }^{1, *}$

${ }^{1}$ Pontificia Universidad Católica Chile, Escuela de Antropología, Santiago- Chile. UMR 8220 LAMS (CNRS-Sorbonne Université)- UMR8096 ArchAm (CNRS-Paris 1 Panthéon Sorbonne), Paris- France. marcelaasre@gmail.com

* Corresponding autor: Pontificia Universidad Católica Chile, Escuela de Antropología, Santiago- Chile. UMR 8220 LAMS (CNRS-Sorbonne Université)- UMR8096 ArchAm (CNRS-Paris 1 Panthéon Sorbonne), Paris- France. marcelaasre@ gmail.com

\begin{abstract}
From the literature research review of studies that involved the physicochemical characterization of rock art paintings in Argentina and Chile, we evaluate the impact of this analytic approach in our understanding of these visual and material practices in the southern region of South America. We identify the techniques, protocols and sample preparation, the information obtained, and archaeological questions addressed with these analyses. Consequently, we propose the need for a microarchaeological approach. We stress the materiality and particularities of the rock art practice, as an action performed over continuously altered walls, which forms complex microstratigraphies. Moreover, we highlight the benefits of obtaining comparable results with the use of paintings on different supports and contexts to hold an Archaeology of Color that allows studying not only the meaning, but also understand the exploitation, production, and consumption of color, being the painted rock art one form of the final stage of a complex sequence related to color materials.
\end{abstract}

Keywords: Physicochemical characterization, Microstratigraphy, Archaeology of Color, Rock Art, South America.

\section{Introduction}

Discussions around the validity of the style concept in Palaeolithic art studies led to the emergence of a post-stylistic era in the early 1990s (Bahn and Lorblanchet, 1993). This time expanded and displaced rock art studies focused mainly on images analyses to a greater interest on the characterization of their location, their material composition, and dating, and contribute to offering new interpretations of art based on its relations with socio-cultural and historicalrelated processes, and their association with thems such as social identity, gender, and shamanism, among others (Conkey and Hastorf, 1990; Bahn, 1994; Chippindale and Tacon, 1999; Withley, 1999; Sanz et al., 2009; McDonald and Veth, 2012; Sanz and Fiore, 2014). This movement implied the introduction and application of new methodological techniques, parallel to the technical advancement observed in other disciplines, such as mapping techniques and Geographical Information System (GIS) (Wienhold and Robinson, 2017), digitalization of rock art records (Brady et al., 2017), analysis of images with specific informatics programs (Cerrillo-Cuenca and Sepúlveda, 2015), and the implementation of systematic physicochemical analyses, between others (Clottes et al., 1990; Rowe, 2001; Chalmin et al., 2003; Reiche and Chalmin, 2014; Bonneau et al., 2012; Huntley and Freeman, 2016; Sepúlveda, 2016; Tomasini et al., 2016; Chalmin and Huntley, 2017;). Like what happened in 
other archaeology-related areas, the collection of new complementary data at different scales broadened our understanding of the painted and engraved rock art representations. This paradigmatic change was defined as the Third Science Revolution (Kristiansen, 2014), and led researchers to not only re-think archaeological practice and the role of archaeology as a discipline but also our interrogations and our relation to objects (Pollard and Bray, 2007; Olsen et al., 2012; Martinón-Torres and Killick, 2015).

Both in Argentina and Chile, the physicochemical analysis and characterization of pigments in the southern portion of South America, has gained relevance in the last decades (Sepúlveda, 2011; Sepúlveda et al., 2012; Carden et al., 2014; Tomasini et al., 2016). The publications related to this topic have shown the richness of the available analytical approaches, including microscopic ones, but also elemental, structural, molecular or crystallographic techniques. This archaeological science or archaeometric movement, thus, rarely discusses the methodological implication of the use of one technique over another, their advantages and/or limitations, the sampling protocols, and the sample preparation, for example. It has also failed to discuss the complexity in the interpretation of results so they could be socio-culturally significant, and not only a chemical result (Boschín et al., 2002; Sepúlveda, 2009, 2011 and 2016; Sepúlveda and Laval, 2010a; Gheco et al., 2013 and 2019; Tomasini et al., 2016).

Beyond these necessary precautions, as the result of a literature review, we evaluate the research questions addressed by those interdisciplinary studies that have incorporated the use of physicochemical characterization to the study of rock art paintings in Argentina and Chile. More specifically, we identified the techniques used, the stratigraphic sample preparation, and the obtained information concerning research questions, to evaluate how these elements have broadened our view on rock art in the southern portion of the South American continent. Our review delves into a discussion of the need for a microstratigraphic approach in the study of rock art, and we reflect upon its importance for the development of an Archaeology of Color, where the materiality of the visual images is paramount for their study and interpretation, as well as for their comparison to other painted material objects or supports. We consider rock art production as a way of consuming colors by past populations, impossible to understand if not studied in its entirety, i.e. with results that allow discussing the collection of raw materials, their preparation and application, and their use in different objects, supports, and contexts.

\section{Rock art studies in Argentina and Chile}

The first mentions of rock art in these regions, including arid environments to the north and the Patagonian steppe landscapes to the far south, began by the end of the nineteenth century. These visual manifestations include engraved and painted representations, but also geoglyphs (Briones, 2006; Fiore y Hernández Llosas, 2007; Sepúlveda, 2005). Until the 1990s, most of the research conducted emphasized rock art descriptions, interpretation of their meaning through historical or ethnographic sources, their iconographical analysis, and stylistic definition. This was done to propose relative chronologies to organize these visual representations found in different regions and localities and to compare rock art figures with motifs found on other supports and to understand their continuities and change through time (Podestá, 1996 and 2003; Gallardo et al., 2006). Throughout years, the link between rock art and their archaeological contexts not only integrated the art expressions with the activities identified at those sites but also allowed interpreting the compositions and scenes in different styles with socio-historical processes characteristic of each chronological period or phase (Fiore and Hernández Llosas, 2007; Fiore, 2012; Podestá and Strecker, 2014; Sepúlveda et al., 
2016; Troncoso et al., 2017 and 2018; Valenzuela and Montt, 2018). Gradually, the study of rock art images incorporated into their results the analysis of other materials (lithics, bones, ceramic, and architecture) for reconstructing their associated contexts and to interpret their location and place in the landscape with other human landmarks, pathways, and settlements. Leaving behind interpretations restricted to their cultic, magic-religious, or aesthetic dimension, since the 1990s decade, rock art has been understood as cultural and visual evidence of ancient human populations that inhabited the various regions of the Southern portion of the continent.

Coinciding with the technical advancement reached in other disciplines (Brothwell and Pollard, 2001), as well as the theoretical shift of New Archaeology and its impact in South American archaeology (López et al., 2012; Sepúlveda, 2016), by the end of the 1970s, the first physicochemical characterization of rock art paintings was conducted (Iñiguez and Gradin, 1977). These studies would increase by the 1980s (Aschero, 1983-1985 and 1985; Barbosa and Gradin, 1986-1987; Niemeyer, 1986) and more notoriously from the 1990s onwards (Hedges et al., 1997; Hernández Llosas et al., 1998; 1999; Belardi et al., 2000; Wainwright et al., 2000; 2002a; 2002b; Niemeyer and León, 2001; Boschín et al., 2002; 2011; Ledesma, 2005; Vásquez et al., 2008; Yacobaccio et al., 2008; Sepúlveda, 2009 and 2011; Vásquez et al. 2010; Nazar et al., 2010; Sepúlveda and Laval 2010b; Masaferro et al. 2012; Sepúlveda et al., 2012; 2013a; 2013b; 2014; 2015a; 2015b; Tomasini et al., 2012a and 2016; Gheco et al., 2013; 2015; 2017 and 2019; Carden et al., 2014; Castelleti et al., 2015; De La Fuente and Nazar, 2016; Moya et al., 2016; Tascon et al., 2016; Troncoso et al. 2017; Rousaki et al. 2017 and 2018; Brook et al., 2018;). Even though the majority of these studies provide data on color variation, some of them go in-depth on their chronology, providing the first direct dating of rock art paintings in the various regions of the Southern portion of the Southern continent (Hedges et al., 1997; Hernández Llosas et al., 1998 and 1999; Castelleti et al., 2015; Goguitchaichvili et al., 2016; Troncoso et al., 2017).

This new tendency in rock art studies in the southern portion of South America was, without doubt, motivated and influenced by two significative publications of Carlos Aschero (19831985 and 1988). He was the first to propose the production sequence concept for rock art interpretation. He also presented a flowchart model with references to the archaeological remains precisely related to each of the stages in this sequence. Inspired on Schiffer model flux (1976) he suggested several phases including the obtention of raw material, the manufacture of rock art, the uses or functional aspects and then the abandonment of the site. After the uses, he considered the possibility of recycling or maintenance of painting images. After the first occupation of the site, the cycle can start again since the first stage linked to the provisioning of raw material. This Aschero model was specified with three operative chains described by Fiore in 2007. She added to the operative chain of image production, the tool production used for rock art engraving or painted, and an operative chain strictly related to painting production. The painting production is particularly relevant as Fiore considers all steps since resource procurement including manufacture, use, maintenance, eventual recycling and finally discard, loss or abandonment and storage. She then enlarges painting conception not just limited to images conception and representation, including the raw materials (pigment and binders) and artifacts involved in their fabrication.

For this review, we only considered those publications on rock art paintings that included physicochemical results on pigments, excluding those works concerned with their dating and whose compositional analysis have been previously published (Goguitchaichvili et al., 2016, Troncoso et al., 2017). A similar and previous synthesis was realized for Argentine by López 
and collaborators (2012), but they considered all works published in Argentinean and Latin American congress proceedings, between 2005 and 2011, related to pigments analysis and not only to rock art painting but also to ceramics and pigments from archaeological contexts. For our purpose, in Table 1, we indicate authors, year, country, region and language of the publication. We also precise the different analytical techniques used in the sample preparation for stratigraphic analysis. In Table 2, we include specific information about the explicit results related to the palette of color, the elemental and mineralogical identification for each color and organic components when they were identified. Finally, we point out three aspects discussed with the physicochemical results: dating or chronological implications for representational styles defined in each region, the production, technology or "chaîne opératoire" of rock art, and the provenance question. In total, 46 articles were registered between 1977 and 2019 in different regions from Argentina and Chile (Figure 1).

\section{3.-Literature review: Physicochemical characterization of rock art paintings from the Southern portion of South America}

The first study that included the physicochemical analysis of paintings was published in the 1970s on sites from Argentinean Patagonia (Iñiguez and Gradin, 1977; Table 1). This number increased to four in the 1980s, including the first study carried out in Chile on paintings from El Médano in the town of Taltal, located on the coast of the Antofagasta region (Niemeyer, 1986). It was not until the first decade of 2000 that publications increased to thirteen (Tables 1 and 2). Finally, 23 studies were published in the last decade (2011-2019), i.e. 50\% of the total publications to this date (Tables 1 and 2). In sum, 33 studies have been performed in different regions of Argentina: 21 in the northwest part of the country (almost 63,6\%), fourteen in Patagonia, and only two present results that included both regions (Wainwright et al., 2002a and 20022b; Figure 1 and Table 1). From these numerous studies, only thirteen have been carried out on rock art paintings in Chile (Figure 1): nine in different localities in the north, and one each in the semi-arid north (Moya et al., 2016), Central Chile (Niemeyer and León, 2001) and Patagonia (Sepúlveda, 2009). This shows a clear concentration of studies in different localities of the Atacama Desert (Figure 1; Table 1). Concerning the publication language, 29 have been in Spanish, 16 in English, and only one in French. More interestingly, 62,5\% of these English articles have been published in the last six years, i.e. $21,7 \%$ of the total studies centered on the physicochemical characterization of pigments (Table 1). This shows a clear increase of publications in English in the last years, a tendency observed, for example, in Chilean archaeology in general (Gurruchaga and Salgado, 2017). Despite this internationalization effort, there is a still low impact of Argentinean and Chilean studies on physicochemical rock art analyses, mainly led by United States, Europe and Australia (Clottes et al., 1990; Rowe, 2001; Bonneau et al., 2012; Beck et al., 2013; Reiche and Chalmin, 2014; Chalmin and Huntley, 2017; between others).

\section{1.- Physicochemical techniques used}

In terms of techniques, destructive chemical tests have only been performed on two occasions (Belardi et al., 2000; Boschín et al., 2002; Table 1). Initial research was made towards the end of the 1980s with the use of X-Ray Diffraction (XRD), a useful technique for the analysis of crystalline solids (Iñiguez and Gradin, 1977; Aschero, 1983-1985 and 1985; Rial and Barbosa, 1983-1985a and 1983-1985b). From the 1990s different techniques began to be combined for material analysis, adding the use of Scanning Electron Microscope with Energy Dispersive Xray Spectroscopy (SEM-EDX), Infrared spectroscopy (FTIR) or X-Ray Diffraction (DRX) for 
molecular characterization (Hedges et al, 1997; Wainwright et al. 2000, 2002a and 2002b; Vasquez et al. 2008 and 2010), and less commonly X-Ray Fluorescence (XRF) for identifying both major and minor elements in a sample (Belardi et al., 2000; Niemeyer and León, 1986). During these times, the use of SEM-EDX was carried out essentially to obtain an elemental characterization of samples and was only replaced with the use of XRF in specific cases, as both provide a similar elemental chemical information. In 1997, techniques for detecting organic material were applied in Argentina to identify them and perform the first direct dating of rock art in the country (Hedges et al., 1997).

The use of SEM-EDX for acquiring images was carried out for the first time at the beginning of the 2000 decade (Boschín et al., 2002), probably due to the influence of the Fundación Tarea team and their previous experience with analyzing easel paintings from the colonial era (Seldes et al., 1999 and 2002). This same team would then delve into the identification of organic components used for the preparation of paintings through different chromatographic techniques (GC-MS, pyrolysis GC-MS, HPLC; Boschín et al., 2002 and 2011; Vásquez et al., 2008; Tomasini et al., 2012a and 2016). The use of Raman spectroscopy for molecular analysis increased only in the last decade, since 2010. This is understandable considering the development of the technique and its recent application to heritage and archaeological sectors for being a non-destructive and non-invasive technique (Bellot-Gurlet et al., 2006; Casadio et al., 2016; Lydzba and Madariaga, 2016). Also, to this date and in contrast to what has been observed in other regions of the world (Huntley and Freeman, 2016; Mauran et al., 2019), the application of non-destructive portable techniques has occurred in only three rock art studies. One analysis was performed with a portable XRF on red colors in coastal and lowland sites from the far North of Chile (Sepúlveda et al., 2015a; Table 1). Two others concern Raman portable analysis in the Patagonian region from South Argentina (Rousaki et al. 2017 and 2018; Table 1).

Since the beginning of these physicochemical applications, the lack of portable equipment determined the need for sample extractions for the different analyses and the necessity to define specific protocols for these sampling (Boschín et al., 2002; Sepúlveda, 2009; Tomasini et al., 2016). Besides, until the 1990s the type of equipment available in Argentina and Chile conditioned, in many cases, that painting samples extracted in the field were pulverized or submitted to chemical treatments before analysis. Whilst these treatment protocols are useful for the analysis of rocks and other mineral materials, they are currently inadequate for rock art analysis, as they mix the characterization of the surface, the layers of paintings and the occasional patinas (Sepúlveda, 2016; Tomasini et al., 2016; Gheco et al., 2017 and 2019). This is why we repeatedly encounter, for example, discussions on the identification of gypsum, to which we commonly find two alternative interpretations: its relation to the preparation of the rock surface before painting, or its intentional addition to the painting's composition (Aschero, 1988; Hernández Llosas et al., 1998; Nazar and De La Fuente 2010; Boschín et al., 2011; De La Fuente and Nazar, 2016; Gheco et al., 2019). However, these studies rarely discussed the election of the analytical techniques used, as well as sample preparation procedures, to evaluate these aspects and their impact on the interpretations proposed.

\section{2.- Synthesis of principal results}

Despite the limitations mentioned, results obtained in more than 40 years of studies offer an overview of the raw materials used and, in some cases, reveals the complexity of the applied recipes for the production of the paintings. This is because of the identification not only of the 
colorant material but also of the presence of extenders and/or organic materials as binding agents (Boschín et al., 2002; Sepúlveda et al., 2012).

For the red color generally, the use of iron oxides, mostly haematite, is identified as colorants (Table 2), but haematite-based mixtures were also identified. In some cases, mixes were with aluminosilicates, possibly clays, where the presence of iron oxides was not specified either because they were indistinguishable or because they were naturally present (Sepúlveda, 2009; Table 2). The quantity and type of aluminosilicates, as well as iron oxides, had an impact on the tone variability of red (light to dark red and brownish red; Wainwright et al., 2002a; Yacobaccio et al., 2008; Nazar et al., 2010). Other authors defined mixtures elaborated with iron oxides, clays and salt like oxalates or calcium carbonates (Aschero, 1983-1985; Hernández Llosas et al., 1999; Wainwright et al., 2002a; Nazar et al., 2010; Massaferro et al., 2012; Carden et al., 2014; Gheco et al., 2015; De La Fuente y Nazar, 2016).

Yellow has been obtained through different colorants like goethite, although in several cases the use of jarosite has been identified (Iñiguez and Gradin, 1977; Massaferro et al., 2012; Table 2). The limonite was identified by Raman spectroscopy at Patagonia (Boschin et al. 2002 and 2011; Vásquez et al. 2010). In other cases, there is evidence of different components, but none that can explain clearly the color obtained (Hernández Llosas et al., 1999; Wainwright et al., 2002a).

White constitutes, without doubt, an unresolved topic of great complexity, because of the difficulty to distinguish the painting's composition from salts like gypsum (calcium sulfate dihydrate; $\left.\mathrm{CaSO}_{4} \cdot \mathrm{H}_{2} \mathrm{O}\right)$, calcium oxalates $\left(\mathrm{CaC}_{2} \mathrm{O}_{4}\right)$, calcium carbonates $\left(\mathrm{CaCO}_{3}\right)$, but also titanium dioxide $\left(\mathrm{TiO}_{2}\right)$ sometimes also presented and observed on the support (Rousaki et al. 2018; Table 2). Of course, this discussion depends on the technique used for the analysis. Thus, for white color the use of aluminosilicates as clays, gypsum, calcium oxalates (whewellite or wheddellite), quartz, and calcite have been identified (Hernández Llosas et al., 1999; Wainwright et al., 2002a; Nazar et al., 2010; Massaferro et al., 2012; Carden et al., 2014; Gheco et al., 2015; De La Fuente y Nazar, 2016; Rousaki et al. 2018).

For black, like other regions in the world (Sepúlveda et al., 2015b), the use of manganese oxide with or without barium has been identified with elemental techniques, like SEM-EDX or XRF (Sepúlveda et al., 2012), and pyrolusite, manganite or cryptomelane have been determined through molecular techniques like Raman spectroscopy; although, cryptomelane have only been observed in Northern Chile (Sepúlveda et al., 2015b). Pyrolusite has also been recognized in sites from Patagonia (Wainwright et al., 2002a and 2002b). In the analysis of black pigment samples, the repeated use of carbon (charcoal) in different moments of the regional chronological sequences of the North and South of the southern portion of the South American continent is surprising. In effect, the scarce availability, as well as the restricted access to manganese sources in such regions could have impacted the use of charcoal; however, this selection can also highlight a specific material and technological choices for this color.

Finally, green was commonly obtained through green earth (Wainwright et al., 2002a and 2002b; Boshin et al. 2011; Rousaki et al. 2018). Other studies identified the use of different types of copper minerals, like atacamite or bandylite, determined at an elemental level as copper sulfates, -oxides and -chlorides, identified only in different localities of the Atacama desert and in the semi-arid North in Chile (Sepúlveda et al., 2013 and 2014; Moya et al., 2016, respectively). 
Most of these colorant materials identified (haematite, goethite, jarosite, manganite, cryptomelane, copper minerals between others) had a mineral origin. They can be obtained from different types of sources as vein exposed or carved, in powder or rocky form with different degrees of compaction. They can also be obtained from available rock fragments on the surface.

Equivalent to other regions in the world, organic components have been scarcely analyzed (Pepe et al., 1991) given the preservation issues (degradation, dissolution or others) associated to the application of painting on the rock supports (chemical processes) and its consequential exposure and interaction with the surrounding environment. Only five publications in Argentina and Chile have found organic components, identified through different chromatographic techniques, like GC-MS, pyrolysis GC-MS, HPLC (Boschín et al., 2002; Vásquez et al., 2008; Yacobaccio et al., 2008- the two last works concerned samples from the same site) or merely observed in the SEM-EDX, due to the impossibility of characterizing them through this technique (Sepúlveda, 2009 and 2011). The use of animal fat in red and black paint mixtures is identified in rock art paintings from Patagonia and Northwest Argentina (Boschín et al., 2002; Vásquez et al., 2008 and Yacobaccio et al., 2008, respectively). In Chile, we observed through SEM-EDX dark amorphous stains without specific forms and wooden structures characterized by the presence of carbon-based components. The wooden charcoal can be identified with the combination of image and spectra obtained with the SEM-EDX (Sepúlveda, 2009). In paintings from the north and southern Chile, the presence of bone fragments has also been observed as part of the paint mixture (Sepúlveda, 2009 and 2011, respectively), which could hypothetically imply their use as colorant material, as is shown in ethnographies from the south of the continent (Manzi, 1991). However, its incorporation into the mixture could be accidental, as bone instruments could be used for its preparation.

\section{3.- Archaeological questions addressed with physicochemical analysis}

In terms of research interrogations, most of the studies have focused on characterizing the color palette, i.e. assessing the identification of colorant materials and the possibility to interpret variation of colors and the different tones observed. Studies concerned in general the red color, as it is also the principal color used in Argentinean and Chilean rock art, and in many of the analyzed sites it is the only color used (Table 2). That is why the available results become relevant, as they demonstrate the variability of raw materials and mixtures produced.

Related to these results, another topic studied in these regions of South America has been influenced by Aschero's (1988) and Fiore's (2007). Following Cresswell and Lemonnier, Aschero understands the production, maintenance, and recycling of rock art in terms of a sequence of stages. This first model was later improved by Fiore (2007) who developed a more complex scheme including three operative chains that stem from the theory of technology and refers both to the cognitive operations and practical hand-made operations carried out. Much of the work realize afterward have followed this path by discussing the technologies utilized in the production of paintings and the identification of recipes (Yacobaccio et al., 2008; Sepúlveda, 2009 and 2011; Boschín et al., 2011; De La Fuente y Nazar, 2016; Table 2). Expanding the study on the production sequence of rock art, some authors included the analysis of raw material sources to discuss the provenance of the main colorants or extenders with naturally containing colorants (e.g. clays) (Iñiguez y Gradin, 1977; Aschero, 1983-1985; Belardi et al., 2000; Wainwright et al., 2002b; Ledesma, 2005; Yacobaccio et al., 2008; Boschín et al., 2011; Massaferro et al., 2012; Sepúlveda et al., 2012, 2013a, 2013b, 2014a and 2015b; Table 2). The problem is that the majority used molecular or crystallographic 
techniques as DRX or FT-IR instead traces elemental analysis as Neutron Activation Analysis (NAA), Particle Induces X-Ray Emission (PIXE) or Inductively Coupled Plasma Mass Spectrometry (ICP-MS), for example, more adequate for this kind of problems as they are more sensitive and can identify trace elements to finally discriminate between samples with similar elementary and/or molecular composition (Popelka-Filcoff et al., 2008; Chalmin and Huntley, 2017; MacDonald et al., 2018).

Other investigations were oriented towards obtaining direct dating based on the results obtained from the physicochemical characterization of paintings (Hedges et al., 1997; Hernandez Llosas et al., 1998 and 1999; Castelleti et al., 2015; Goguitchaichvili et al., 2016; Troncoso et al., 2017; Brook et al., 2018; Table 2). However, even without direct dating, several studies have discussed the implications of results from their chemical analysis on the previously identified art styles in various localities. In other words, they interpret the variability of pigments and mixtures identified to go in-depth on the relative chronological sequences of the art (Aschero, 1983-1986; Gheco et al., 2013; Castelleti et al., 2015; Table 2).

Another topic discussed from physicochemical analysis concern the conservation of paintings, and the recording of preservation states of sites and panels, which are a requisite for the correct interpretation of analytical results (Tomasini et al., 2012a and 2016; Sepúlveda, 2016; Rousaki et al., 2018; Gheco et al., 2019). These observations can bring us chemical information later identified by analytical techniques and can be related to the support characteristics, or the presence of water runoffs, concretions or patinas or others, and not necessarily to the chemical composition of rock art paintings. Another aspect discussed by some authors concerns the implications for rock art interpretations of the chemical analysis employed, the methodologies and protocols applied. They evaluate, for example, the consequences of the use of one technique over others and discussed the implication of the results obtained following the research questions raised. They also compared the advantages of elemental over crystallographic techniques, the use of scanning electron microscopy over other analytical techniques, the preparation of samples in resin for stratigraphic analysis, and its consequence for specific archaeological questions (Tomasini et al., 2012a and 2016; Sepúlveda, 2009 and 2016; Sepúlveda and Laval, 2010b; Sepúlveda and Wright, 2018; Gheco et al., 2017, 2019 and 2020).

In synthesis, since the 1970s in both Argentina and Chile, there has been a development of rock art studies through the physicochemical characterization of paintings, mainly focusing on identifying colorants to understand rock art technology with stylistic and chronological implications. Less commonly these studies have focused on conservation issues, the methodological consequences of choosing one technique over other or the effect of sample preparation types in the analysis of rock art. The formation of interdisciplinary teams, as well as international collaborations, have been fundamental in defining which techniques are used (Hedges et al., 1997; Boschín et al., 2002 and 2011; Sepúlveda y Laval, 2010a and 2010b; Sepúlveda et al., 2012, 2013a and 2013b; Masaferro et al., 2012; Castelleti et al., 2015; Tascon et al., 2016; Brook et al., 2018). Nonetheless, there is little continuity in this study field, appearing mostly as sporadic and opportunistic collaborations, which demonstrate the lack of long-term research programs that integrate archaeometric techniques to the study of rock art. Thus, it is evident that results obtained and the use of techniques in each case study has been subject to equipment availability, and financial resources. Despite these advances, very few studies have considered and reflected upon the nature and particularities of rock art paintings. Materially speaking, these paintings are a mixture of different components mixed and applied over a fragile rock surface and submitted to constant environmental agents (Boschin et al., 
2011; Sepúlveda and Wright, 2018; Gheco et al., 2020). The human occupational history of the site contributes to forming complex microstratigraphies on rock art panels (Nazar et al., 2010; Tomasini et al., 2016; Chalmin et al., 2017; Gheco et al., 2017 and 2019). This is why we agree with the need for a microarchaeological approach to the study of the materiality of rock art paintings, which keeps in scope the specificities of these practices, but also secures results that can be compared with other material objects and support painted (Sepúlveda et al., 2014a and $2014 b$ ). From our perspective, with the study of the materiality of color, we will be able to understand and compare exploitation, production, and consumption of material colored (Sepúlveda et al., 2019). In this perspective, rock art paintings are considered one of the forms of color consumption.

\section{4.- Microarchaeology for rock art studies.}

The preparation of paints implies the combination of the colorant material with other components, extenders and/or binding agents, that enable or facilitate its adhesion or increase its amount (Petit and Valot, 1991; Sepúlveda and Wright, 2018). Some pigments could be heated to modify their properties (Pomiès et al., 1999; De La Fuente and Nazar 2016). The identification and characterization of the painting components can be obtained through elemental, molecular and crystallographic analysis, used single or combined according to the component to be analyzed and the research question (Chalmin et al., 2003; Vásquez et al. 2008; Yacobaccio et al., 2008; Boschín et al., 2011; Huntley et al., 2011; Bonneau et al. 2012; Sepúlveda, 2016; Chalmin and Huntley, 2017; Sepúlveda and Wright, 2018; Gheco et al., 2020). Then, before choosing a protocol for analysis it is inevitable to first understand the nature of the rock art paintings, i.e. as a combination of different components, but also the fact of its application over the rock support, with which a chemical as well as mechanical (considering the pores or voids of the rocks) interaction is formed (Nazar et al., 2010; Tomasini et al., 2016). Once applied and exposed to changing environmental conditions, the preparation can be altered or superficial patinas can form over the painting and block its visibility (Nazar et al., 2010; Chalmin et al., 2017). Moreover, there may be retouching of the original painting or simply the intentional addition of new superimposed motifs, which mask the original representations (Chalmin et al., 2017; Gheco et al., 2019). The use of the Harris Matrix to illustrate painting sequences with the examination of superimpositions has become increasingly common (Chippindale and Taçon, 1993; Gheco et al, 2017; Dudognon and Sepúlveda 2018; Carden and Miotti 2020). The human occupation of rock art sites can also modify their visibility and contribute to generate a more complex stratigraphy (Gheco et al., 2017 and 2019). For this reason, a microarchaeological approach proves necessary. The analysis of microstratigraphy and its micro-excavation, also known as the "nano-approach" (Watchman and Hatte,1996), is almost inevitable if we seek to characterize the painting's composition and show stratigraphic sequences (Watchman et al., 2000; Chalmin et al., 2003; Tascon et al., 2016; Bonneau et al., 2017; Gheco et al., 2017 and 2019).

The term microarchaeology can have two definitions. First, it commonly refers to the use of a microscopic recording of material studied through instruments like microscopes, spectrometers, among others, in contrast to the macroscopic approach related to the stratigraphy of a deposit, buildings, floors and artifact assemblages (Weiner, 2010). The second definition considers microarchaeology as a theoretical framework, "a tool-box of concepts and theory, developed to deal with the relationship between social practice and materialities" (Cornell and Fahlander, 2007:7), which provides answers to a problem from a small scale, i.e. the study of unique but repetitive practices, that finally can contribute to understanding the 
general context or structure. In this occasion, we understand the concept of microarchaeology to refer to "a range of techniques [that] are expanding the scope of research into the archaeological past and pushing a wide range of collaborations between archaeologists and specialists" (Chazan, 2018:23); although this author limits its definition to mineralogy, genetics and biochemistry. On this occasion, we will understand the microarchaeology in its merely methodological scope i.e like the application of techniques commonly used in other areas of the sciences to obtain data on a small scale to solve archaeological problems. Expanding on this definition, we recognize the need to excavate and analyze the microscopic component of archaeological artifacts and deposits -and, therefore, the invisible to the naked eye-, to complement data obtained at the macroscopic level. However, by invisible here we do not only mean the chemical dimension, whether this information is atomic, elemental or molecular, but also the possibility of dealing with the immaterial, that is, the knowledge and gestures involved in the production of the material analyzed, in our case rock art paintings (Aschero 1988; Fiore 2007; Sepúlveda, 2009 and 2011) ${ }^{1}$.

Methodologically, microarchaeological analysis entails the preparation of samples in resin to observe the stratigraphy of samples extracted from the field, which makes it invasive but not destructive, as samples can be stored and analyzed again (Plesters, 1956; Tsang and Cunningham, 1991; Wachiowak, 2004; Marte et al., 2011 and 2013; Sepúlveda et al. 2015c; Gheco et al., 2017). Once prepared according to the equipment's requirements, these samples can be analyzed through a combination of different techniques for the identification and characterization of their components, which have well-established and developed procedures in the study of rock art paintings abroad (Chalmin et al., 2003; Bonneau et al., 2012 and 2016, for example). Surprisingly, in Argentina and Chile, very few studies have considered the microstratigraphic analysis of their samples to at least differentiate the composition of the rock surface, pigment layer(s) and superimposed patinas (Boschín et al., 2002 y 2011; Sepúlveda, 2009, Sepúlveda and Laval, 2010, Sepúlveda et al., 2012, 2013a, 2013b, Tomasini, 2012a y 2016; Tascon et al., 2016; Gheco et al., 2017, 2019 and 2020). On the contrary, many studies have used crushed samples for their analyses, so their results refer to the group of components present in all the sample's strata. Therefore, it is difficult to discern the components of the paint used on rock surfaces and patinas, for example, leading to an incorrect interpretation of the results.

The observation and characterization of the different layers present in a sample painting are useful for specifying the components strictly related to the deterioration of a painting (Tomasini et al., 2012a and 2016; Bonneau et al., 2017; Chalmin et al., 2017). Besides, it contributes towards determining the relative sequence of art performance over a panel or in a site (Vignaud et al., 2006; Chalmin et al., 2017; Gheco et al. 2019), establishing associations of strata with the occupation stratigraphy of the archaeological context (Gheco et al., 2019), and identifying layers with material for dating (Watcham and Hatte, 1996; Watchman et al., 2000; Bonneau et al., 2017).

The limitation observed in most of the studies where stratigraphic analysis of samples has been considered is that in general, they have only regarded the observation of layers and their chemical composition. These studies omit in general the description and morphological characterization of the layer contents, as well as the quantification, measurement, and distribution of its components or grains present in each one (Marte et al. 2011 and 2013; to illustrate our purpose see Chalmin et al., 2003; Vignaud et al., 2006; Sepúlveda, 2016; Gheco

\footnotetext{
${ }^{1}$ Other versions of these insights could involve symbolic or ritual topics related with nature.
} 
et al. 2020, as they describe precisely what we want to sustain here). As a consequence, chemical characterization of the different layers, the eventual quantification of their composition, and the mixtures identified are interpreted as the result of different mixtures, or different paint pots, in other words, the elemental and molecular differences correspond to different recipes (Chalmin et al., 2003; Vignaud et al., 2006; Bonneau et al., 2016).

The stratigraphic reading of a sample, its chemical analysis and the observation of its composition, in terms of the identification of different grains, their sizes, morphology, and distribution, can determine technological aspects of the preparation of the painting, such as the degree of grinding of the components and its relation to the color or tone obtained, the intentional elaboration of certain mixtures, the thickness of the layers, and the variation of colors or tones that are the product of the superposition of layers of different thickness, among others (Marte et al., 2011; Sepúlveda, 2016; Gheco et al. 2020). In conjunction with chemical information at an elemental level, this can shed light on raw material sources (Chalmin et al., 2017), as well as on possible alteration processes (Tascon et al., 2016; Tomasini et al., 2016; Chalmin et al., 2017; Gheco et al., 2017 and 2019). Even more, these results enable the comparison of rock art painting production with the colors observed in other material objects or support painted, intending to contrast not only their presence, but also their processing, production and consumption (Aschero, 1988; Fiore, 2007; Sepúlveda, 2011 and 2016; Sepúlveda and Wright, 2018), and the intangible aspects related to these three stages. This is how in two case studies in the Atacama Desert in Northern Chile, we used the same analysis protocols applied on rock art paintings to other material objects painted.

\section{1.- Two cases of microarchaeological approach to color study from the Atacama Desert}

The first case led us to focus on archaic black paints (ca. 7000-3700 years BP) and allowed us to compare contemporary rock art production above 3.0000 m.a.s.l associated to huntergatherers from the highland, and funeral offering and paints used inside and on the coating of Chinchorro mummies, a cultural tradition of hunter-gatherers and fishers from the coast of the northernmost Chilean region (Sepúlveda et al., 2013b, 2014b and 2015b, 2015c). In synthesis, we identified the use of similar manganese minerals, such as pyrolusite, cryptomelane, and manganite. We also compared these results to the characterization of a raw material source located over 5000 m.a.s.1. in the region (Sepúlveda et al., 2014b and 2015b). Even if we identified the same mineral pigments, we also recognize differences indicating specific technological choices (as indicated by Sillar and Tite, 2000). For example, through a microarchaeological study of the coating of mummified bodies, we found the presence of complex stratigraphy's, providing evidence of the repainting of bodies (Sepúlveda et al., 2015c). We do not observe the same recipes nor repaint technique in highland rock art. Apart from the color symbolism, we proved in Chinchorro mummies the existence of care and revitalization practices in the funerary rite from this archaic coastal tradition. Also, we discussed the supply and interaction mechanisms between archaic highland hunter-gatherers and coastal hunter-fisher and gatherers populations, which provides evidence of the value of black pigment in these societies and its importance for establishing social relations (Sepúlveda et al., 2013b and 2015b).

The second case study was related to characterize and understand the production and consumption of blue and green paintings on the rock art of late prehispanic times in the Antofagasta region (Sepúlveda and Laval, 2010b; Sepúlveda et al., 2013a and 2014a). The preliminary observation through microscopy showed, in the rock art from Incahuasi Inca site, located in the highlands, the superimposition of layers, as well as its composition in terms of 
the type of grains, its distribution, and size. These results indicated that blue and green layers were prepared differently to red layers, which were applied in thinner layers. Their elemental characterization through SEM-EDX allowed identifying the morphology and size of grains, as well as provide evidence for the first time of paintings using copper oxides, sulfates and chlorides as a base (Sepúlveda and Laval, 2010b). These components were then identified as atacamite and bandylite through Raman spectroscopy, and results were contrasted with findings on dust and green concretions from an important pre-Inca cemetery in the region (Sepúlveda et al., 2013a). Together, these analyses allowed, in synthesis, inserting copperbased pigment production into a broader context related to the exploitation of these materials for metallurgical and lapidary uses, which were significant technologies in the Atacama Desert since before the start of our era until the $16^{\text {th }}$ Century. To go in-depth on these aspects and evaluate the variability of colorant raw materials used, we broadened our study towards the analysis of other painted surfaces in the neighboring Tarapacá region towards the north, focused on another type of mineral (antlerite) (Sepúlveda et al., 2014a). Through our results, we discuss the implications of regional production in terms of chronology and its importance in the creation of bonds between different entities in the late pre-Inca and Inca times $\left(12^{\text {th }}-16^{\text {th }}\right.$ Century). Raw materials and the knowledge of production-related to pigment technology obtained through copper minerals were greatly appreciated by the Inca at the time of their expansion in the region, and later by the Spanish Colony (Tomasini et al., 2012b).

Both examples provided evidence on different base preparations for the same raw material colorants. Moreover, they contributed to understanding the intangible knowledge related to the provisioning and production of certain paint mixtures, but also with the value of certain materials and know-how related to the production in two different moments of the pre-Hispanic sequence in the Atacama Desert. Its value was such that in certain cases it allowed articulating different social entities through the exchange of raw materials or paints among different localities in this wide desert region. The black pigment was obtained from specific sources present above 4.500 m.a.s.l. and demonstrate that two different traditions: hunter-gatherers from the highland and hunter-gatherers and fishers from the coast developed different forms of consumptions and necessarily had to establish certain relationship mechanisms for its exchange. The blue and green pigment productions were greatly appreciated by the Inca in their expansion to the North of Chile. Later, the circulation of copper pigments through important trade routes from the $17^{\text {th }}$ Century, shows that the knowledge associated with their exploitation and the technology developed in the Atacama Desert was preserved to paint religious cult objects of the Spanish Colonial period (Tomasini et al., 2012b).

Consequently, a microarchaeological study of these different practices enables the comparison of different forms of consumption on rock art painting but also on other supports and contexts, that functioned, without doubt, in an articulated way. Therefore, it is necessary to consider all steps of pigment production and uses since its first stages of exploitation and the raw material extraction to different forms of application and presence in different archaeological contexts. Finally, in these distinct steps other types of knowledge were involved, add to the value and significance of the colors, that can be understood from the study of its materiality.

\section{An Archaeology of Color for rock art studies}

The Archaeology of Art proposed in the last decades (Sanz et al., 2009; Jone and Cochrane, 2018), and the impact of the Third Revolution, and in specific with the effect of material sciences in these visual practices, without any doubts has broadened our view, but also the 
understanding of rock art studies, overcoming mere descriptive approaches (Bahn, 1994; MacDonald and Veth, 2012). This commonly observed tendency in Europe, United States, South Africa, and Australia, has equally influenced studies carried out in the Southern portion of South America. However, in our continent, we recognize some limitations in the availability of equipment, specialized laboratories, lack of funding, but also in academic training that allow assessing rock art through recent analytical and archaeometrical approaches (see also López et al., 2012). One illustration of that last aspect refers to that many studies have used crushed samples for their analyses and lost information about the history of the formation of images painted on rock surfaces. Consequently, it is difficult to discern the components of the paint used on rock surfaces and patinas, for example, leading to an incorrect interpretation of the results. That's why the excess in optimism and trust in the value of these techniques from hard sciences for answering archaeological questions is for example played down by Sørensen (2017). This author reminds us that more important than accumulating quantitative data is to set good research questions that can be further addressed from different points of view. In other words, we must not forget to reflect upon the way archaeologists set their research questions (see also Martinón-Torres and Killick 2015).

In this sense, it is necessary to highlight our research questions related in general, for example, on human-environment, human-human, or human-object interactions, and then reflect upon the relevance of a microarchaeological approach for their study. The characterization and the accumulation of chemical results by themselves simply provide more data on a figure, a panel a site, localities, and regions in rock art studies. However, what are the social implications of these results? Based on the specific questions addressed, what techniques are the most adequate ones? How do we interpret these results and a large amount of data obtained? What we are dating? among others.

Given our perspective on an Archaeology of Art, we agree that this approach "must begin with the analysis of materials, rather than an overarching reliance on written oral accounts" (Jones and Cochrane, 2018: 19). Also following Jones and MacGregor's (2002) proposal on an Archaeology of Color, we consider this framework valid with the study of the materiality of color, which has come closer to understanding immaterial practices, technological choices (see Sillar and Tite, 2001) and values related to the use of colorants in the past. In the Atacama desert, we worked with societies for which we do not have a clear testimony of color significance in different social spheres and daily life, so it is difficult to precise how colors were perceived by the ancient societies in the past, for example, but we can discuss how there were valued since their materialization (Young, 2006). In terms of material culture, the extraction, production, and consumption of color have been immersed in complex and varied social relationships that involved different economic, social, political and ideological spheres in human populations throughout history (cf. Gage, 1999). Therefore, color is embedded within a complex net of relationships and contexts that, at the same time, assign value to pigment (Young, 2006). So here, we do not only looked for what people did with their colorful materials in their social practice dynamics (Young, 2002; for rock art considerations see Sanz et al. 2009), nor to analyze color symbolism or its visual effects (Jones and MacGregor, 2002), we are rather focused in understanding the color materialization from a microarchaeological methodological perspective. The study of the materiality of paint involves, among other things, the specification of the physical properties of its matter, i.e. composition and structure (Tite, 2001), but also the study of all objects or instruments related to its preparation (grinding instruments, brushes, pouches, containers, between others). Nonetheless, we believe that this overconfidence cannot make us forget that, behind these results, we seek not only to understand forms of human interaction with their surroundings, e.g. through the exploitation and ascription 
of meaning to certain raw materials and landscapes (Sepúlveda et al., 2019), but also to know how immaterial knowledge and the value of color articulated interactions between humans, individuals, and different social entities.

\section{6.- Conclusion}

Results resumed in this bibliographic review for Argentina and Chile the rock art research developed in the last years demonstrate a growing interest to include physicochemical characterization of pigments and other paint compounds. We demonstrate the necessity to think about analytical protocols used with consideration to the particularity of rock art paintings. For example, the microstratigraphy became unavoidable for their analysis, but most notably for the interpretation of the results obtained (see also recently Gheco et al. 2020). Many questions will remain difficult to answer if we continue to analyze rock art paintings based on ground samples. Moreover, these considerations are fundamentals to study the paint production sequence that brings relevant information about ancient technologies, immaterial knowledge related to colorant materials, their provenance, the possibility to obtain direct dating and to discuss this chronological information to improve our understanding of rock art practices. This approach also contributes to understanding that the use of color is not limited to rock art but participate in other material productions.

These interrogations, problems, and results resumed for Argentinean and Chilean rock art are very similar to what has been observed and described in other parts of the world (Rowe, 2001; Chalmin et al., 2003; Reiche and Chalmin, 2014; Bonneau et al., 2012; Huntley and Freeman, 2016; Chalmin and Huntley, 2017). Our bibliographic review demonstrates how in the southern cone of South America, a region rarely integrates into other published synthesis, can contribute to the debate issue of the physicochemical applied to rock art studies. Despite similitudes observed with other countries, some results remain to be unique. For example, that's the case resumed in this work and related to copper minerals used as pigments exploited, crushed and mixed to other compounds to obtain blue and green paints applied on rock surfaces. The chromatic palette offers by pigment minerals available in the Atacama desert in northern Chile is very unusual compared to the other regions from the country, Argentina and other parts of the world. In the South American continent, we can find some similitudes in mural paintings from the Central Andes in pre-Columbian Peru (Wright, 2010 and 2014; Sepúlveda and Wright, 2018).

Since our experience, we understand that painting production not only concerns its application onto rocky support, as it can be applied to other materials objects or supports. Pigments and paints can also be stored and preserved for future applications or to be offered to deaths during funerary practices (Sepúlveda et al. 2019). The prevailing preservation conditions in the Atacama Desert have, of course, contributed to our work, and the development of a comparative approach to color in the past. Color allows us to study different dimensions of life and daily practices in past societies (Jones and MacGregor, 2002; Boivin, 2004), being rock art paintings one form of color consumption. Through a microarchaeological approach, we propose to make visible the invisible, in terms of the immaterial knowledge involved in its production and that enabled the articulation of different social entities, to attempt to reconcile theory and method in archaeology (Jones 2004).

The Third Science Revolution have without doubt implied a movement of archaeological practice with the obtention of a new type and precise information at a microscale analysis, 
between other possibilities, about the objects studied. After the opportunities brought by radiocarbon dating, for example, the use of physicochemical techniques offers opportunities to explore the past, to review old interpretations, and to contribute to developing new theories about material culture and the ancient human societies. In this opportunity, we advocate for an Archaeology of Color with a synthetic perspective that includes not only an innovative methodological approach but a broader view of color since our interest in its materiality.

\section{Acknowledgments}

This work was funded by FONDECYT 1190263 in Chile and Inca Project from OPUS Program at Sorbonne Université in France. I am very grateful for LAMS laboratory hospitality's this last 4 years and to my colleague and friend Philippe Walter for its generous support and permanent advice. My acknowledgment to Benjamin Ballester, Lucas Gheco, Matías Lepori, Noemi Mastrangelo for bibliographic references, and to Ana Paula Motta and Daniela Osorio to review the English version. Finally, thanks to Danae Fiore and an anonymous reviewer for their precious commentaries which contribute to improving the first version.

\section{References}

Aschero, C., 1983-1985. Pinturas rupestres en asentamientos cazadores recolectores: dos casos de análisis aplicando difracción de Rayos X. Cuadernos del Instituto Nacional de Antropología 10, 291-306.

Aschero, C., 1985. Notas sobre el uso de pigmentos minerales en el sitio CCP-5, Provincia de Santa cruz, Argentina, In: Aldunate, C., Berenguer, J., Castro, V. (Eds.), Estudios en arte rupestre. Primeras jornadas de arte y arqueología. Museo Chileno de Arte Precolombino, Santiago de Chile, pp. 13-24.

Aschero, C., 1988. Pinturas rupestres actividades y recursos naturales: un encuadre arqueológico, in: Yacobaccio, H., Borrero, L., García, L.C., Politis, G., Aschero, C., Bellelli, C. (Eds.), Arqueología contemporánea Argentina; actualidad y perspectiva. Ediciones Búsqueda, Buenos Aires, pp. 209-142.

Bahn, P., 1994. Some new developments in Ica age art. Complutum 5, 197-202.

Bahn, P., Lorblanchet, M., 1993. Introduction, in: Lorblanchet, M., Bahn, P. (Eds.), Rock art studies: the post-stylistic era o where do we go from here? Papers presented in symposium of the 2nd Aura Congress, Cairns 1992. Oxbow Monograph 35, Oxford, pp. v-viii.

Barbosa, C.E, Gradín, C., 1986-1987. Estudio composicional de difracción de rayos X de pigmentos del Alero Cárdenas, Provincia de Santa Cruz. Relaciones XVII (1), 143-171.

Beck, L., Genty, D., Lahlil, S., Lebon, M., Terwygol, F., Vignaud, C., Reiche, I., Lambert, E., Valladas, H., Kalnecker, E., Plassard, F., Menu, M., Paillet, P., 2013. Non-destructive portable analytical techniques for carbon in situ screening before sampling for dating prehistoric rock paintings. Radiocarbon 55 (2-3), 436-444. 
Belardi, J. B., Súnico, A., Puebla, D.N., 2000. Análisis de pigmentos minerales y sus fuentes potenciales de aprovisionamiento en el área del Lago Roca (Sector Chorrillo Malo), Provincia de Santa Cruz (Argentina). An. Inst. Patagonia 28, 291-304.

Bellot-Gurlet, L., Pagès-Camagna, S., Coupy, C., 2006. Raman spectroscopy in art and archaeology. J. Raman Spectrosc. 37, 962-965.

Boivin, N., 2004. From veneration to exploitation. Human engagement with mineral world, in: Boivin, N., Owoc, M.A. (Eds.), Soils, stones and symbols. Cultural perceptions of the mineral world. Routledge, London and New York, pp. 1-29.

Bonneau, A., Pearce, D. G., Pollard, A. M., 2012. A multi-technique characterisation and provenance study of the pigments used in San rock art, South Africa. J. Archaeol. Sci. 39(2), 287-294.

Bonneau, A., Staff, R.A., Higham, T., Brock, F., Pearce, D.G., Mitchell, P.J., 2016. Successfully dating rock art in the southern Africa using improved sampling methods and new characterisation and pretreatment protocols. Radiocarbon: 1-19. DOI:10.1017/RDC.2016.69

Bonneau, A., Pearce, D., Mitchell, P., Staff, R., Arthur, C., Mallen, L., 2017. The earliest directly dated rock paintings from southern Africa: new AMS radiocarbon dates. Antiquity 91(356), 322-333.

Boschín, M. T., Maier, M., Massaferro, G., 2011. Une lecture pluridisciplinaire des analyses chimiques et minéralogiques de peintures rupestres de la Patagonie argentine. L'Anthropologie $115,360-383$.

Boschín, M.T., Seldes A., Maier, M., Casamiquela, R., Ledesma, R., Abad, G., 2002. Análisis de las Fracciones Inorgánica y Orgánica de Pinturas Rupestres y Pastas de Sitios Arqueológicos de la Patagonia Septentrional Argentina. Zephyrus 55: 183-198.

Brady, L. M., Hampson, J., Domingo Sanz, I., 2017. Recording rock art: strategies, challenges, and embracing the digital revolution, in David, B., McNiven, I.J. (Eds.), The Oxford Handbook of the archaeology and anthropology of rock art. Online version. DOI: 10.1093/oxfordhb/9780190607357.013.37.

Briones, L., 2006. The geoglyphs of the north Chilean desert: an archaeological and artistic perspective. Antiquity 80, 9-24.

Brook, G., Franco, N., Cherkinsky, A., Acevedo, A., Fiore, D., Pope, T., Weimar III, R., Neher, G., Evans, H., Salguero, T., 2018. Pigments, binders, and ages of rock art at Viuda Quenzana, Santa Cruz, Patagonia (Argentina). J. Archaeol. Sci.: Reports 21, 47-63.

Brothwell, D.R., Pollard, A.M., 2001. Handbook of archaeological sciences. John Wiley and Sons Ltd, Chichester.

Carden, N., Blanco, R., Poiré, D., Genazzini, C., Magnin, L., García, P., 2014. Análisis de pigmentos del macizo del deseado: el abastecimiento de materias primas y la producción de pinturas rupestres en cueva Maripe (Santa Cruz, argentina). Relaciones de la Sociedad Argentina de Antropología XXXIX (2), 483-508. 
Carden, N., Miotti, L., 2020. Unraveling rock art palimpsests through superimpositions: The definition of painting episodes in Los Toldos (southern Patagonia) as a baseline for chronology. J. Archaeol. Sci: Reports 30. https://doi.org/10.1016/j.jasrep.2020.102265

Casadio, F., Daher, C., Bellot-Gurlet, L., 2016. Raman spectroscopy of cultural heritage materials: overview of applications and new frontiers in instrumentation, sampling modalities, and data processing. Top Curr. Chem. (Z) 374, 62. DOI 10.1007/s41061-016-0061-z.

Castelleti, J., Goguitchaichvili, A., Solís, C., Rodríguez Ceja, M., Morales, J., 2015. Evidencia de tempranas manifestaciones rupestres en la costa del Desierto de Atacama $\left(25^{\circ} \mathrm{S}\right)$. Arqueología Iberoamericana 28, 16-21.

Cerrillo-Cuenca, E., Sepúlveda, M., 2015. An assessment of methods for the digital enhancement of rock art paintings: The rock art from the precordillera of Arica (Chile) as a case study. J. Archaeol. Sci. 55, 197-208.

Chalmin, E., Menu, M., Vignaud, C., 2003. Analysis of rock art painting and technology of Paleolithic painters. Meas. Sci. Technol.14, 1590-1597.

Chalmin, E., Castets, G., Delannoy, J.-J., David, B., Barker, B., Lamb, L., Soufi, F., Pairis, S., Cersoy, S., Martinetto, P., Geneste, J.-M., Hoerle, S., Richards, T., Gunn, R., 2017. Geochemical analysis of the painted panels at the "Genyornis" rock art site, Arnhem Land, Australia. Quat. Int. 430, 60-80.

Chalmin, E., Huntley, J., 2017. Characterizing rock art pigments, in David, B., McNiven, I.J. (Eds.), The Oxford Handbook of the archaeology and anthropology of rock art. Online version. DOI: 10.1093/oxfordhb/9780190607357.013.48.

Chazan, M., 2018. World Prehistory and Archaeology. Pathways through time. Routledge, New York.

Chippindale, C., Taçon, P., 1993. Two old painted panels from Kakadu: variation and sequence in Arnhem Land rock art, in Steinbring, J., Watchman, A, Faulstich, P, Taçon P. (Eds.), Time and Space: dating and spatial considerations in rock art research. Papers of Symposia F and E, AURA Congress, Cairns 1992. Australian Rock Art Research Association, Melbourne, pp. 3256.

Chippindale, C., Taçon, P., 1999. The archaeology of rock art. Cambridge University Press, UK.

Clottes, J., Menu, M., Walter, P., 1990. La préparation des peintures magdaléniennes des cavernes arriégeoises. Bull. de la Soc. Prehi. Franc. 87(6), 170-192.

Conkey, M., Hastorf, C., 1990. The uses of style in archaeology. Cambridge University Press, UK.

Cornell, P., Fahlander, F., 2007. Encounters-Materialities-Confrontations. Archaeologies of social space and interaction. Cambridge Scholars Press, UK. 
De La Fuente, G., Nazar, C.D., 2016. Pintores antiguos, tecnología y pigmentos: aportes para la reconstrucción de las cadenas operativas implicadas en la producción de las pinturas de la Tunita, Motegasta y La Resfalosa (Departamentos Ancasi y La Paz, Catamarca Argentina), in: Oliva, F., Rocchietti, A.M. Solomita, F. (Eds.), Imágenes rupestres, lugares y regiones. Centro de Estudios Arqueológicos Regionales, Centro de Arqueología Histórica, Cooperadora Asociación José Pedroni, Agencia Nacional de Promoción Científica y Tecnológica, Rosario, Argentina, pp. 181-194.

Domingo Sanz, I., Fiore, D., May, S.K., 2009. Archaeologies of art: time, place and identity in rock art, portable art, and body art, in Domingo Sanz, I., Fiore, D., May, S.K. (Eds.), Archaeologies of art: time, place and identity, Left Coast Press, Inc. Walnut Creek, CA, pp. $15-27$.

Domingo Sanz, I., Fiore, D., 2014. Style: its role in the archaeology of art, in: Smith C. (Ed.) Encyclopedia of Global Archaeology. Springer, New York, NY. https://doi.org/10.1007/978$1-4419-0465-2$

Dudognon, C., Sepúlveda, M. 2018. Rock art of the upper Lluta valley, northernmost of Chile (South Central Andes): A visual approach to socio-economic changes between Archaic and Formative periods (6,000e1,500 years BP). Quat Int 491: 136-145.

Fiore, D., 2007. The economic side of rock art: concepts on the production of visual images. Rock Art Res. 24(2): 149-160.

Fiore, D., 2012. Materialidad visual y arqueología de la imagen. Perspectivas conceptuales y propuestas metodológicas desde el sur de Sudamérica. B. Mus. Chil. Arte Prec. 16(2), 101119.

Fiore, D., Hernández Llosas, M.I., 2007. Miradas rupestres. Tendencias en la investigación del arte parietal en Argentina. Relaciones de la Sociedad Argentina de Antropología XXXII, 217242.

Gallardo, F., Montt, I., Sepúlveda, M., Pimentel, G., 2006. Nuevas perspectivas en el estud1o del arte rupestre. B. SIARB 20, 77-87.

Gheco, L.I., Quesada, M.N., Ybarra, G., Poliszuk, A., Burgos, O., 2013. Espacios rupestres como «obras abiertas»: una mirada a los procesos de confección y transformación de los abrigos con arte rupestre del este de Catamarca (Argentina). Revista Española de Antropología Americana 43(2), 353-368.

Gheco, L., Poliszuk, A., 2015. Caracterización química de pinturas rupestres prehispánicas del sitio arqueológico de Oyola mediante SEM-EDS, DRX, FT-IR, FRX y GC-MS (Catamarca, Argentina), in: Pifferetti, A.A., Dosztal, I. (Eds.), Arqueometría argentina, metodologías científicas aplicadas al estudio de los bienes culturales: datación, caracterización, prospección y conservación. Aspha, Buenos Aires, pp. 271-284

Gheco, L., Gastaldi, M., Marte, F., Quesada, M., Tascon, M., Mastrangelo, N., 2017. About fires and paintings: three stratigraphic insights on the history of a cave with prehispanic rock art. J. Archaeol. Sci.: Rep. 15, 48-58. 
Gheco, L., Tascon, M., Ahets Etcheberry, E., Quesada, N., Marte, F., 2020. Looking for Painting Mixtures to Glimpse Pictorial Techniques: A Micro-Stratigraphic Physicochemical Approach to the Rock Art From the Oyola's Caves (Argentina). J. Heritage Sci. Under Review. DOI: $10.21203 /$ rs.3.rs-21330/v1

Gheco, L., Tascon, M., Gastaldi, M., Ahets Etcheberry, E., Pereda, S., Mastrangelo, N., Quesada, M., Marte, F., 2019. Hidden paintings, forgotten histories: a micro- stratigraphic approach to study coated rock art. Archaeol. Anthrop. Sci. https://doi.org/10.1007/s12520-01900854-z

Goguitchaichvili, A., Morales, J., Urrutia- Fucugauchi, J., Soler Arechalde, A.M., Acosta, G., Castelleti, J, 2016. The use of pictorial remanent magnetization as a dating tool: state of the art and perspectives. J. Archaeol. Sci.: Rep. 8, 15-21.

Gurruchaga, A., Salgado, M., 2017. Publicación científica bajo criterios hegemónicos: explorando la realidad arqueológica chilena. Revista Chilena de Antropología 35, 148-163. doi:10.5354/0719-1472.2017.46643.

Hedges, R.E.M., Bronk Ramsey, C., Van Klinken, G.J., Pettit, P.B., Nielsen-Marsh, C., Etchegoyen, A., Fernandez N., J.O., Boschín, M.T., Llamazares, A.M., 1998. Methodological issues in the $14 \mathrm{C}$ dating of rock paintings. Radiocarbon 40 (1), 35-44.

Hernández Llosas, M. I., A. Watchman y J. Southon.1998. Fechado absoluto y análisis de pigmentos para las pinturas rupestres de Pintoscayoc (Departamento Humahuaca, Jujuy). Estudios Sociales del NOA 2 (1): 31- 60.

Hernández Llosas, M. I., A. Watchman y J. Southon. 1999. Pigment analysis and absolute dating of rock paintings from Jujuy, Argentina, in: Strecker, M, Bahn, P. (Eds.), Dating and the earliest known rock art. Oxbow Books, Oxford, pp. 67-74.

Huntley, J., Watchman, A., Dibden, J., 2011. Characteristics of a pigment art sequence: woronora plateau, New South Wales. Rock Art Res. 28(1), 85-97.

Huntley, J., Freeman, C.F., 2016. The material scientific investigation of rock art: Contributions from non-invasive x-ray techniques, in: Bednarik R.G, Fiore, D., Basile, M., Kumar, G., Huisheng, T. (Eds.), Paleaoart and materiality. Oxford University Press, Oxford, pp. 41-58.

Iñíguez, A.M., Gradin, C.J., 1977. Análisis mineralógico por difracción de rayos X de muestras de pinturas de la Cueva de las Manos, Estancia Alto Río Pinturas (Provincia de Santa Cruz). Relaciones de la Sociedad Argentina de Antropología 11, 121-128.

Jones, A.M., 2004. Archaeometry and materiality: materials-based analysis in theory and practice. Archaeometry 46(3): 327-338.

Jones, A.M., Cochrane, A., 2018. The archaeology of art. Materials, practices, affects. Routledge, UK.

Jones, A.M., Macgregor, A., 2002. Colouring the past. The significance of colour in archaeological research. Berg, Oxford and New York. 
Kristiansen, K., 2014. Towards a new paradigm? The Third Science Revolution and its possible consequences in archaeology. Curr. Swed. Archaeol. 22,11-34.

Ledesma, R., 2005. Contexto de producción de pinturas rupestres en el divisadero (departamento de Cafayate, provincia de Salta, Argentina). Andes 16, 305-324.

López, M.A., De la Fuente, G.A., Fiore, D, 2012. Arqueometría del arte: estudios físicoquímicos de pigmentos arqueológicos. B. Mus. Chil. Arte Prec. 17 (2), 75-81.

Lydzba- Kopczynska, B., Madariaga, J.M., 2016. Applications of Raman spectroscopy in art and archaeology. J. Raman Spectrosc. 47: 1404-1407.

MacDonald, B.L., William, F., Dubreuil, L., Beddard, J., Pidruczny, A., 2018. Iron oxide geochemistry in the Great Lake Region (North America): implications for ochre provenance studies. J. Archaeol. Sci.: Rep. 19, 476-490.

MacDonald, J., Veth, P., 2012. Research issues and new directions. One decade into the new millennium, in: MacDonald, J., Veth, P. (Eds.), A Companion to Rock Art. Blackwell Publishing Ltd, UK, pp. 1-14.

Manzi, L. 1991. Obtención, manufactura y usos de pinturas en grupos de cazadoresrecolectores pedestres de la isla grande de Tierra del Fuego: un enfoque sistémico, in: Podestá, M.M., Hernández Llosas, M.I, Renard de Coquet, S.F. (Eds), El arte rupestre en la arqueología contemporánea. Buenos Aires, Argentina, pp. 139-149.

Martinón-Torres, M., Killick, D., 2015. Archeological theories and archaeological sciences. In Gardner, A., Lake, M., Sommer, U. (Eds.), The Oxford Handook of Archaeological Theory, Oxford Handbooks Online. doi:10.1093/oxfordhb/9780199567942.013.004.

Massaferro, G., Arrigoni, G., Boschín, M.T., Fernández, M., Crivelli, E.A., Cordero, J.A., 2012. Indicadores de tecnología y etnodinamia: el análisis de pigmentos en el paraje arqueológico Comallo Arriba, provincia de Río Negro, Argentina. B. Mus. Chil. Arte Prec. 17 (1), 117-127.

Mauran, G., Lebon, M., Détroit, F., Benoit, C., Nankela, A., Pleurdeau, D., Bahain, J.J., 2019. First in situ pXRF analyses of rock art paintings in Erongo, Namibia: results, current limits and prospects. Archaeol. Anthropol. Sci. doi:10.1007/s12520-019-00787-7

Marte, F., Mastrangelo, N., Tascon, M., 2011.The art of measuring: optical microscopy applied to the measurement of transversal sections. Eadem Utraque Europa 13, 257-268.

Marte, F., Mastrangelo, N., Tascon, M., 2013. The art of measuring II: challenges in measuring particles in cross-sections. Eadem Utraque Europa 14, 245-254.

Monnier, G. 2018. A review of infrared spectroscopy in microarchaeology: Methods, applications, and recent trends. J. Archaeol. Sci.: Rep. 18, 806-823.

Moya, F., Troncoso, A., Sepúlveda, M., Cárcamo, J.J., Gutiérrez, S., 2016. Pinturas rupestres en el norte semiárido de Chile: una primera aproximación físico- química desde la cuenca del río Limarí (30 Lat. S.). B. Mus. Chil. Arte Prec. 21(2), 47-64. 
Nazar, C., De La Fuente, G., Vera, S.D., 2010. Estudios tecnológicos y de composición de mezclas pictóricas de La Tunita, Catamarca, Argentina, in: Bárcena, J.R., Chiavazza, H. (Eds.), Actas del XVVI Congreso Nacional de Arqueología Argentina, Tomo II. Univ. Nacional de Cuyo and Consejo Nacional de Investigaciones Científicas y Técnicas, Mendoza, pp. 913-918.

Niemeyer, H., 1986. Proyecto de Arte Rupestre Quebrada El Médano. Boletín de la Sociedad Chilena de Arqueología 4.

Niemeyer, H., León, V., 2001. Arte rupestre Precolombino en el Tinguiririca, Provincia de Colchagua, Sexta Región de Chile. Gráfica Escorpio, Santiago.

Olsen, B., Shanks, M., Webmoor, T., Witmore, C., 2012. Archaeology. The discipline of things. University of California Press, Berkeley, Los Angeles, London.

Pepe, C., Clottes, J., Menu, M., Walter, P., 1991. Le liant des peintures Paléolithiques ariégeoises. Compte-rendu de l'Académie des Sciences 312(8), 929-934.

Petit, J., Valot, H., 1991. Glossaire des peintures et vernis des substances naturelles et des matériaux synthétiques. Section Francaise de l'Institut Internacional de Conservation, Association des Restaurateurs d'Art et d'Archéo-logie de Formation Universitaire and Institut Francais de Restauration des Oeuvres d'Art, Saint-Etienne, France.

Plesters, J. 1956. Cross-sections and chemical analysis of paint samples. Studies in Conserv. 2, 110-157.

Podestá, M., 1996. South America yesterday and today in Argentina's rock art, in: Bahn, P., Fossati, A. (Eds). Rock Art Studies. News of the World 1. Oxbow, Oxford, pp. 225-229.

Podestá, M., 2003 Rock Art Research in Argentina at the end of the millennium, in: Bahn, P., Fossati, A. (Eds). Rock Art Studies. News of the World 3. Oxbow, Oxford, Pp. 242-251.

Podestá, M., Strecker, M., 2014. South American Rock Art. In C. Smith (Ed.), Encyclopedia of Global Archaeology. Springer, New York, pp. 6828-6841.

Pollard, A.M., Bray, P. 2007. A Bicycle Made for Two? The Integration of Scientific Techniques into Archaeological Interpretation. Annu. Rev. Anthropol. 36: 245-259.

Pomiès, M.-P., Menu, M., Vignaud, C., 1999. Red paleolithic pigments: natural hematite or heated goethite. Archaeometry 41(2), 275-285.

Popelka-Filcoff, R.S., Miksa, E., Robertson, J.D., Glascock, M., Wallace, H., 2008. Elemental analysis and characterization of ochre sources from Southern Arizona. J. Archeol. Sci. 35, 752762.

Reiche, I., Chalmin, E., 2014. 14.15-Synchrotron methods: Color in paints and minerals, in: Holland, H.D., Turekian, K.K. (Eds.), Treatise on geochemistry (2nd ed.,). Elsevier, Oxford, pp. 209-239. 
Rial, G., Barbosa, G. 1983-1985. Análisis mineralógico por difracción de rayos X de muestras de pinturas del cerro Casa de Piedra, sitio CCP5 (Provincia de Santa Cruz, República Argentina). Cuadernos del Instituto Nacional de Antropología 10, 307-311.

Rousaki, A., Vásquez, C., Aldazábal, V., Bellelli, C. Carballido, M, Hadjuk, A., Vargas, E., Palacios, O., Vandenabele, P., Moens, L., 2017. The first use of portable Raman instrumentation for the in situ study of prehistoric rock paintings in Patagonian sites. J. of Raman Spesctrosc. 48(11): 1459-1467.

Rousaki, A., Vargas, E., Vásquez, C., Aldazábal, V., Bellelli, C. Carballido, M, Hadjuk, A., Vargas, E., Palacios, O., Moens, L., Vandenabele, P., 2018. On-field Raman spectroscopy of Patagonian prehistoric rock art: Pigments alteration products and substrata. Trends Anal. Chem. 105: 338-351.

Rowe, M.W., 2001. Physical and chemical analysis, in: Whitley, D. (Ed.), Handbook of Rock Art Research. Walnut Creek, Altamira Press, pp. 190-220.

Seldes, A.M., Burucúa, J.E., Maier, M.S., Abad, G., Jáuregui, A., Siracusano, G., 1999. Blue pigments in South American painting (1610-1780). J. Am. Inst. Conserv. 38(2), 100-123.

Seldes, A., Burucúa, J.E., Siracusano, G., Maier, M. S., Abad, G.E. (2002). Green, yellow, and red pigments in South American painting, 1610-1780. J. Am. Inst. Conserv. 41(3), 225-242.

Sepúlveda, M., 2005. Arte rupestre del extremo Norte de Chile: evaluación crítica y nuevas perspectivas de análisis, in: Giorgi, C., De l'Altiplano mexicain à la Patagonie: Travaux et recherches à 1'Université de Paris 1. BAR International Series 1389- Paris Monographs in American Archaeology 16. Archaeopress, Oxford, England, pp. 227-236.

Sepúlveda, M. 2009. Aspectos tecnológicos en la pintura rupestre. Reflexiones elaboradas a partir de análisis físico-químicos aplicados al estudio de las pinturas de la localidad del río Salado (norte de Chile), in: Sepúlveda, M., Briones, L., Chacama, J. (Eds.), Crónicas sobre la piedra. Arte Rupestre de las Américas. Ediciones Universidad de Tarapacá, Arica, pp. 119128.

Sepúlveda, M. 2011. Pinturas rupestres y tecnología del color en el extremo sur de Chile. Magallania 39 (1), 193- 210.

Sepúlveda, M. 2016. Methodological approach to the materiality of rock art paintings based on their physicochemical characterisation. Proposal and reflections from their study in Chile, in: Bednarik R.G, Fiore, D., Basile, M., Kumar, G., Huisheng, T. (Eds.), Paleaoart and materiality. Oxford University Press, Oxford, pp. 59-72.

Sepúlveda, M., Arriaza, B., Standen, V., Rousseliere, H., Van Elslande E., Santoro, C., Walter, P., 2015c. Análisis microestratigráficos de recubrimientos corporales de una momia Chinchorro, extremo norte de Chile. Chungara 47 (2), 239-247

Sepúlveda, M., Cabello, G., Valenzuela, D., 2016. Rock art in Chile (2010-2014), in: Bahn, P., Franklin, N., Strecker, M., Devlet, K., Rock Art Studies. News of the world V. Archaeopress Publishing Ltda, Oxford, UK, pp 349-364. 
Sepúlveda, M., Figueroa, V., Cárcamo, J.J., 2014a. Pigmentos y pinturas de minerales de cobre en la región de Tarapacá, norte de Chile: nuevos datos para una tecnología pigmentaria prehispánica. Estud. Atacamenos 48, 23-37.

Sepúlveda, M., Figueroa, V., Pagès-Camagna, S., 2013a. Copper pigment making in the Atacama Desert (northern Chile). Lat. Am. Antiq. 24(4), 467-482.

Sepúlveda, M., Gallardo, F., Ballester, B., Cabello, G., Vidal, E., 2019. El Condor mine: prehispanic production and consumption of hematite pigments in the Atacama Desert, northern Chile. J. Anthropol. Archaeol. 53, 325- 341.

Sepúlveda, M., Gutierrez, S., Cárcamo, J.J., Oyaneder, A., Valenzuela, D., Montt, I., Santoro, C., 2015a. In situ X-Ray Fluorescence analysis of rock art painting sites along the coast and valleys of the Atacama Desert, northern Chile. J. Chil. Chem. Soc. 60(1), 2822-2826.

Sepúlveda, M., Gutierrez, S., Campos- Vallette, M., Standen, V., Arriaza, B., Cárcamo, J.J., 2015b. Micro-Raman spectral identification of manganese oxides black pigments in archaeological context in Northern Chile. J. Heritage Sci. 3, 32. DOI 10.1186/s40494-0150061-2.

Sepúlveda, M., Laval, E., 2010a. Aplicación y aplicabilidad de métodos físico-químicos para el estudio de las pinturas rupestres. Ejemplo de estudio en la localidad del río Salado (II Región, norte de Chile), in: Actas del XVII Congreso Nacional de Arqueología Chilena 2006, Tomo II. Kultrún, SCHA, Valdivia, pp. 825-834.

Sepúlveda, M., Laval, E., 2010b. Uso de minerales de cobre en la pintura rupestre de la localidad del río Salado (II región, norte de Chile), in: Actas del XVII Congreso Nacional de Arqueología Chilena 2006, Tomo II. Kultrún, SCHA, Valdivia, pp. 111-1124.

Sepúlveda, M., Laval, E., Cornejo, L., Acarapi, J., 2012. Elemental characterisation of prehispanic rock art and arsenic in Northern Chile. Rock Art Res. 29 (1), 93-106.

Sepúlveda, M., Rousseliere, H., Van Elslande, E., Arriaza, B., Standen, V., Santoro, C., Walter, P., 2014b. Study of color pigments associated to Archaic chinchorro mummies and grave goods in Northern Chile (7.000- 3.500 B.P.). J. Heritage Sci. 2, 7. doi: 10.1186/20507445-2-7.

Sepúlveda, M., Valenzuela, D., Cornejo, L., Lienqueo, H., Rousseliere, H., 2013b. Óxidos de manganeso en el extremo norte de Chile: abastecimiento, movilidad y producción del color negro durante el período arcaico. Chungara 45(1), 143-159.

Sepúlveda, M., Wright, V., 2018. Pigmentos, pinturas rupestres y murales, in: Chapoulie, R., Sepúlveda, M., Del Solar-Velarde, N., Wright, V. (Eds.), Arqueometria. Estudios analíticos de materiales arqueológicos. Ediciones IFEA, Université Bordeaux-Montaigne y Universidad de Tarapacá. Lima, Perú, pp. 369-392.

Sillar, B., Tite, M., 2000. The challenge of technological choices for materials science approaches in archaeology. Archaeometry 42, 2-20. 
Sørensen, T.F., 2017). The two cultures and a world apart: archaeology and science at a new crossroads. Nor. Archaeol. Rev. 50(2):101-115.

Tascon, M., Mastrangelo, N., Gheco, L., Gastaldi, M., Quesada, M., Marte, F., 2016. Microspectroscopic analysis of pigments and carbonization layers on prehispanic rock art at the Oyola's caves, Argentina, using a stratigraphic approach. Microchem. J. 129, 297-304.

Tite, M.S., 2001. Overview - Materials study in archaeology, in: Brothwell, D.R., Pollard, A.M. (Eds.), Handbook of Archaeological Sciences. John Wiley and Sons Ltd, Chichester, pp. 443448.

Tomasini, E., Basile, M., Ratto, N., Maier, M., 2012a. Evidencias químicas de deterioro ambiental en manifestaciones rupestres: un caso de estudio del oeste Tinogasteño (Catamarca, Argentina). B. Mus. Chil. Arte Prec. 17 (2), 27-38.

Tomasini, E., Rúa, C., Siracusano, G., Maier, M., 2012b. Atacamite as a natural pigment in a South American colonial polychrome sculpture from the late XVI century. J. Raman Spesctrosc. 44: 637-642.

Tomasini, E., Basile, M., Maier, M., Ratto, N., 2016. Proposal of a protocol for the interdisciplinary study of rock art, in: Bednarik R.G, Fiore, D., Basile, M., Kumar, G., Huisheng, T. (Eds.), Paleaoart and materiality. Oxford University Press, Oxford, pp. 1-14.

Troncoso, A., F. Armstrong and M. Basile. 2017a. Rock art in central and south America: social settings and regional diversity, in: David, B., McNiven, I.J. (Eds.), The Oxford Handbook of the archaeology and anthropology of rock art. Online version. DOI: 10.1093/oxfordhb/9780190607357.013.53.

Troncoso, A., Armstrong, F., Nash, G., 2018. Contemporary approaches to rock art in South America: Introductory remarks., in: Troncoso, A., Armstrong, F., Nash, G., Archaeologies of Rock Art. South American Perspectives. Routledge London \& New York, pp. 1-19.

Troncoso, A., Moya, F., Sepúlveda, M., Cárcamo, J.J., 2017b. First absolute dating of hunter gatherers rock art painting from North Central Chile. Archaeol. Anthropol. Sci. 9(2), 223-232. DOI 10.1007/s12520-015-0282-z.

Tsang, J.S., Cunnigham, R. 1991. Some improvements in the study of cross sections. J. Am. Inst. Conserv. 30(2), 163-177.

Valenzuela, D., Montt, I., 2018. Exploring rock paintings, engravings and geoglyphs of the Atacama Desert through materiality, style and agency, in: Troncoso, A., Armstrong, F, Nash, G. (Eds.), Archaeologies of Rock Art. South American Perspectives. Routledge, UK, pp. 179216.

Vásquez, C., Albornoz, A., Hadjuk, A., Maury, A.M., Boeykens, S., 2010. Patrimonio rupestre en el Alero El Maqui, valle encantado, Patagonia: caracterización química inorgánica de pigmentos, in: Palacio, O., Vázquez, C. (Eds), Patrimonio Cultural: la Gestión, el Arte, la Arqueología y las Ciencias exactas aplicadas. CONEA Centro Atómico Constituyentes Editorial Talleres Gráficos, Argentina, pp. 225-232. 
Vázquez C., M. Maier, S. D. Parera, H. Yacobaccio y P. Solá 2008. Combining TXRF, FT-IR and GC-MS information for identification of inorganic and organic components in black pigments of rock art from Alero Hornillos 2 (Jujuy, Argentina). Anal. Bioanal. Chem. 391 (4), $1381-1387$.

Vignaud, C., Salomon, H., Chalmin, E., Geneste, J.M., Menu, M., 2006. Le groupe des 'bisons adossés' de Lascaux. Étude de la technique de l'artiste par analyse des pigments. L'Anthropologie 110, 482-499.

Wachiowak, M., 2004. Efficient new methods for embedding paint and varnish samples for microscopy. J. Am. Inst. Conserv. 43(3), 205-226.

Wainwright, I.M.N., Helwig, K., Podestá, M.M., Bellelli, C., 2000. Analysis of pigments from rock painting sites in Río Negro and Chubut provinces, in: Podestá, M.M., De Hoyos, M. (Eds.), Arte en las rocas. Arte rupestre, menhires y piedras de colores en Argentina. Sociedad Argentina de Antropología, Asociación Amigos del Instituto Nacional de Antropología y Pensamiento Latinoamericano, Buenos Aires, pp. 203-206.

Wainwright, I.M.N., Helwig, K., Rolandi, D., Aschero, C., Gradin, C., Podestá, M.M., Onetto, M., Bellelli, C., 2002a. "Identification of pigments from rock painting sites in Argentina". En L'art avant l'histoire. La conservation de l'art préhistorique. 10èmes journées e'études de la Section francaise de I'insitut international de conservation. París, pp: 15-24.

Wainwright, I.M.N., Helwig, K., Rolandi, D., Gradin, C., Podestá, M.M., Onetto, M., Aschero, C., 2002b. Rock paintings conservation and pigment analysis at Cueva de las Manos and Cerro de los Indios, Santa Cruz (Patagonia), Argentina, in: Preprints of the $13^{\circ}$ Triennial Meeting of ICOM Committee for Conservation, Vol. II. Río de Janeiro, Brasil, pp. 582-589.

Watchman, A., Hatte, E., 1996. A Nano approach to the study of rock art: "The walkunders", Chillagoe, north Queensland, Australia. Rock Art Res. 13(2), 85-92.

Watchman, A.L., David, B., McNiven, I.J., Flood, J.M., 2000. Micro-archaeology of engraved and painted rock surface crusts at Yiwarlarlay (the Lightning Brothers site), Northern Territory, Australia. J. Archaeol. Sci. 27, 315- 325.

Weiner, S., 2010. Microarchaeology. Beyond the visible archaeological record. Cambridge University Press, NY, USA.

Withley, D. 1999. Rock Art Research. Left Coast Press, CA.

Wienhold, M., Robinson, D., 2017. GIS in Rock Art Studies, in David, B., McNiven, I.J. (Eds.), The Oxford Handbook of the archaeology and anthropology of rock art. Online version. DOI: 10.1093/oxfordhb/9780190607357.013.12

Wright, V., 2010. Pigmentos y tecnologíaa artística mochicas: una nueva aproximación en la comprensión de la organización social. Bull de l'Inst Francais d'Études Andines 39(2):299_ 330 . 
Wright, V., 2014. Arqueometría y arte mural prehispánico en el Perú, in: Pozzi-Escot D. (Ed.), Pachacamac: conservación en arquitectura de tierra. Ministerio de Cultura del Perú, Lima, pp. 183-200.

Yacobaccio, H.D., Catá, M.P., Solá, P., Alonso, M.S., 2008. Estudio arqueológico y físicoquímico de pinturas rupestres en Hornillos 2 (Puna de Jujuy). Est. Atacamenos 36, 5-28.

Young, D., 2006. The colours of things, in: Tilley, C., Keane, W., Kuchler, S., Rowlands, M., Spyer, P. (Eds), Handbook of Material Culture. Sage Publications, London, Thousand Oaks, New Delhi, pp. 173-185.

\section{List of Figure}

Figure 1. Localization of all sites mentioned in the text. Chile: 1. La Capilla-1, Vitor 3-A, Ofragía-1, Cruz del Siglo-1, Camarones-19, Huancarane-19; 2. Vilcarauni; 3.- Pampa El Muerto-8; 4.- Tangani-1; 5.- Quebrada Amarga; 6.- San Bárbara-1; 7.- Confluencia; 8.Incahuasi; 9.- El Médano, Miguel Díaz, Piedras Negras, Loreto: 10.- Los Maitenes-1, Melina, Alero La Pintura, Valle El Encanto, Covacha Pintada, La Placa-5, Ponio B, San Pedro Viejo de Pichasca; 11.- Laguna Sarmiento; 12.- Cueva La Leona; 12.- Oosin Aike (see Table 2 for references); Argentina: 1.- Hornillos 2; 2.- Alero de las Circunferencias, Pintoscayoc-1 and Abrigo de los Emplumados; 3.- ICC-4; 4.- Las Juntas; 5.- El Divisadero; 6.- Oyola 4,7,8,13 and 14; 7.- Cueva La Salamanca; 8.- La Candelaria; 9.- Alero La Sixtina, El Hornero, Motegasta, La Resfalosa; 10.- Valle de Las Pinturas; 11.- Cueva Loncomán, Cueva alonso I, Cueva Leleque I, Cueva Comallo I, Ceferino III Fernández 1, Pulupucura I, Buitrera del Cain, Angostura de Cides, Calatreo I, Santa Rosario, Yalaumsca, Maquinchao, Santo Rosario, Campo Mocada 1, Cueva Olate, Alero Las Mellizas, Mirador de Castillo, Alero Maqui, Ouetre Inalef, Guillelmo Lake, Los Rápidos, Cerro Campanario, Cerro Campanario 2, Lago Moreno East, El Trébol, Paredón Lanfré, Campamento Argentino, Angostura Blanca, Piedra Parada 1, Campo Cerda 1; 12.- Azcona; 13.- Peñasco; 14.- Cerro Pintado; 15.- Alero Cardenas; 16.Cueva de Las Manos; 17.- Cerro Los Indios; 18.- CCP-5 and CCP-7; 19.- Alero El Malqui; 20.- Cueva Maripe; 21.- Chorrillo Malo 1,2,6 and 7; 22.- Viuda Quenzana (see Table 2 for references).

\section{List of Tables}

Table 1. Synthesis of rock art studies in Argentina and Chile where physicochemical characterization was considered, including the different techniques used.

Table 2. Synthesis of principal results obtained, and interrogations asked in rock art studies from Argentina and Chile where physicochemical characterization was considered. 


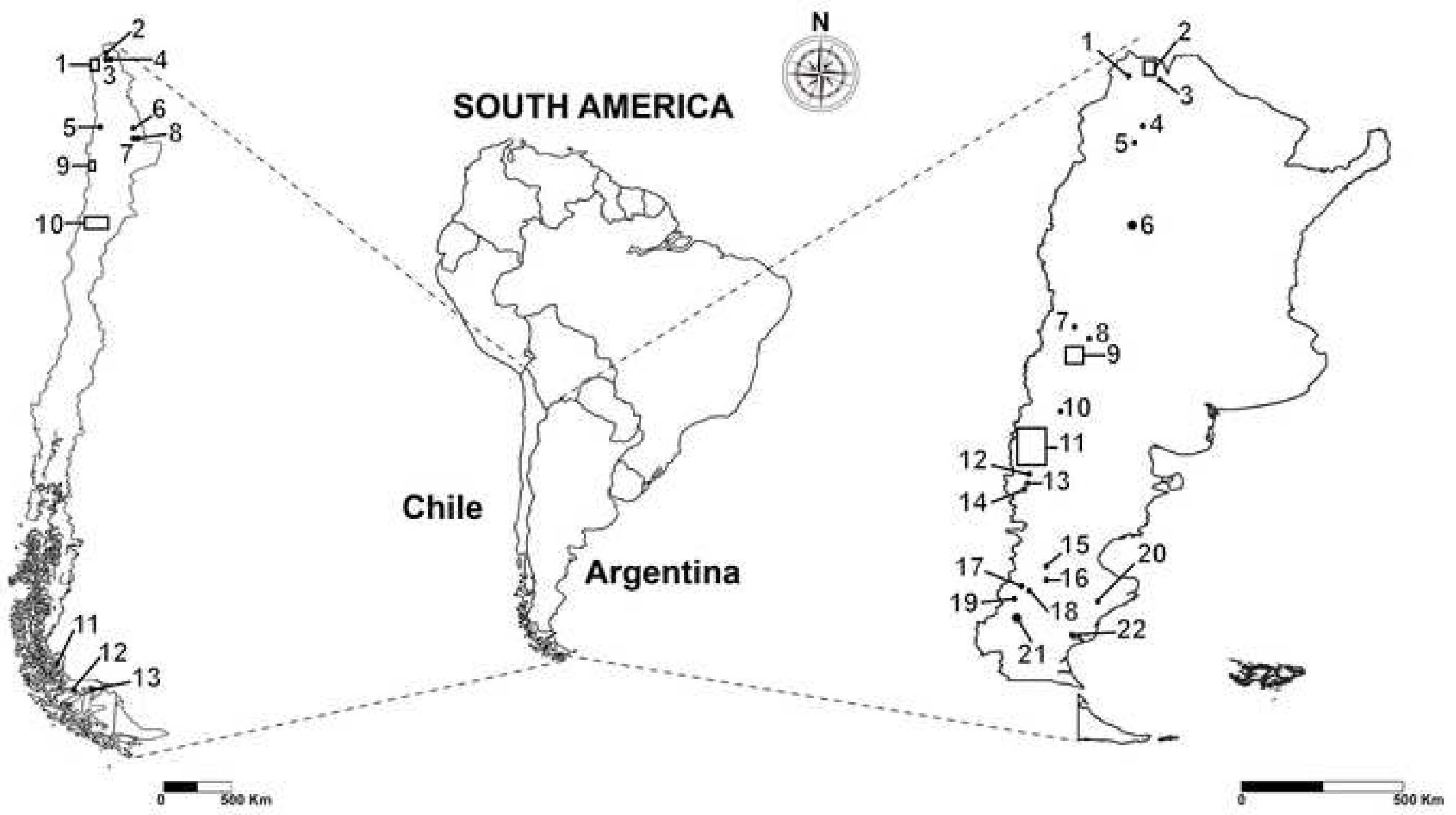


Click here to access/download

Table

Table 1.docx 
Table 2

Click here to access/download

Table

Table 2.docx 